\title{
Computer Technology and Teaching Mathematics in Secondary Schools
}

\section{Sigita TURSKIENÉ}

Šianlici University

P. Višinskio 25, LT-5400 Šiaulicai, Lithuania

('-mail: sigita@fm.su.h

Received: July 2002

Abstract. The paper analyses different aspects of the most popular computer technologies in Lithiania, which are designed or can be easily adjusted to solve mathematical problems. The majo opportunities and problems of introducing computer technologies in teaching proberns. The major The paper deals with teachers' and students' attitudes and prejudices towards the introduction of computer technologies in teaching mathematics. The results show that now it is the most suitable time for the widest integration of various computer technologies in teaching mathematics.

Key words: computer technology, computer mathematics system, teaching of mathematics, computer-based learning. secondary education.

\section{Introduction}

One of the main goals of the educational reform in Lithuania is to reform its educational system in such a way that school leavers are trained for productive work, further studies and life in the rapidly changing information society. That is why the present-day educational system undergoes major changes, and so does the teaching of mathematics. The school syllabus for Mathematics is being amended, with an obvious tendency towards visualisation, construction and modelling. Instead of being oriented towards fragmented knowledge of different subjects, the students are presented with the problem to be solved. Computer technologies can be well employed to achieve these aims.

In Lithuanian secondary schools, next to the term "classes without the computer", the term "classes with the computer" appears. This is a new and essentially different way of teaching in comparison to what it used to be like in Lithuania. It is an open question: how should the introduction of computer technologies in teaching of mathematics be organized to ensure a more effective teaching process and higher quality? Special research is necessary to evaluate how computer technologies influence different areas of mathematics. This is going to be discussed in more detail in other papers of the cycle.

Intensive research is being carried out in Lithuania on the issues of introduction of computer technologies in the teaching of mathematics. Publications on the following issues prove the above-said: fundamentals of working with the MAPLE system and its 
application for solving geometry problems (Turskiene, 2001; Lipeikiene, 2000), the analysis of statistical packages popular in Lithuania and their application in the process of teaching (Rudzikiené, 2000; Rudzikiené 2001), computer technologies and teaching geometry (Dagiené, 2001; Dagiené and Jasutiené, 2001), computer-based modelling and the analysis of the main computer simulation environments (Denisovas, 2000), the link between mathematical software packages MATHCAD and EXCEL (Sérikoviené, 2001), the conjunction between computer algebra and numerical methods (Domarkas, 2001), the opportunities of the MAPLE system for the solution of equations of mathematical physics (Domarkis, 1998), parallel computer algebra system and its application (Judickaité, 2001), etc. A few booklets (Adomavičius, 1999; Barila, 2001; Turskiené, 1997) have been published on the application of MATLAB, MATHCAD and MAThiene, 1997) have tems in the study process.

The literature's review shows wide information technologies application in the study process of Lithuanian Universities. Literature in Lithuanian on how to apply computer mathematics systems in secondary schoois is almost nonexistent (Lipeikiené, 2000; Turskiene, 2002). Websites also have very little information on this issue. An attempt to use computer mathematics systems in Lithuanian secondary school is described at (Using, 2002).

The aim of this paper is to carry out an analytical review of the computer technologies, most suitable for teaching mathematics; to examine and analyse teachers' and students' attitudes and prejudices towards the introduction of computer mathematics systems in teaching mathematics.

\section{The choice of software}

To teach mathematics on the computer, one needs special software. In general the following most widely spread environments, which are directly meant or can be easily adapted for the solution of mathematical problems, can be singled out in Lithuania at present:

1. Universal computer mathematics systems (MAPLE, MATHCAD, MATLAB, MATHEMATICA, DERIVE, etc.);

2. Statistical packages (STATISTICA, STATGRAPHICS, SPSS, SAS);

3. Computer simulation systems (MODEL BUILDER, POWERSIM, etc.);

4. Universal programming languages (Delphi, Visual BASIC, Visual C++, etc.)

5. Spreadsheets (EXCEL, LOTUS 123, etc.);

6. Software for teaching and learning (Geometer's SketchPad, Cabri);

7. Other software: LOGO products (LOGOWRITER, Komenskis' LOGO, etc.), graphing system (ORIGIN, NCSS and PASS), design packages (CAD, etc.).

To work with universal programming languages, one needs rather good programming skills, which often neither students nor subject teachers possess. Besides, programming requires a lot of time. Spreadsheets are simple, easily understood, but their mathematical formulas are cumbersome, difficult to read and modify, and their calculation speed is low. Modelling systems offer an opportunity to manage the process in an interactive way by stimulating the students' creativity, however, the choice of mathematical functions is for the solution work with data array is more difficult. Statistical packages are designed for the solution of statistical problems. Subject teaching and learning software is small, designed to solve problems of a concrete sphere. It is a static software product, while our aim is different. Universal computer mathematics systems have a comfortable while interface, perform numerical and symbolic calculations, have powerful means of graphic images and solve the basic problems of all spheres of mathematics, but the main input commands are written in special internal languages.

A short analytical review of the following most popular in Lithuania universal computer mathematics systems (CMS): MAPLE, MATHEMATICA, MATHCAD, MATLAB, is further carried out. Most of them share the following features:

- the systems have a similar structure. CMS are typical integrated systems, having a text editor, help, various debugger and analysis means, function kernel, libraries, packages, a high level programming language, etc. Having learnt to work with one of them, it is easier to understand another.

- they offer the user similar and comfortable multi-window graphical user interfaces. The work is similar to working in Microsoft Office programmes. It is organized in the form of a document. The user communicates with the system in the form of a dialogue based on the principle "asked a question - the system in answer";

- the work is made easier by the existence of a comfortable help, operating on the principle of a hypertext. In some cases they are an auxiliary means to systematize the knowledge in Mathematics;

- the user can expand the possibilities of the CMS by creating its own programmes and packages;

- to satisfy the needs of various users, CMS are of different modifications; e.g. MAPLE 6 modifications: Power Edition, Standard, Student;

- in all the systems the functions are written in specialized internal languages, which are similar to the universal programming languages C, PASCAL, BASIC One does not need to be a programmer to be able to programme, it is enough to know the basics;

- the systems use symbols that are close to the usual mathematical symbols. In the last versions of all the systems symbol palettes are used to input the data;

- have a simple and comfortable data translation from one system to another. The systems allow generating texts in $C$ and FORTRAN languages. Besides, the texts generated by the systems, can be transferred to the mathematical editor's LATEX
format;

- to better exploit the possibilities of the systems, companies, designing CMS, try integrating their products with the products of other companies. For instance, MAPLE and MATLAB, MAPLE and MS EXCEL, MAPLE and MATHCAD, etc.

- the systems can be used not only by the mathematicians and information technology specialists, but also specialists of other areas. What is important is to be able to write the model of the phenomenon under investigation. 
CMS are comparable according to a few main qualities: the user's graphical interface, the quality of algorithms, calculation opportunities, calculation speed, the quality of graphic images, the level of intellectuality, etc. It is more difficult to compare CMS in accordance with the quality of algorithms, because help does not present algorithms in detail.

How does one choose a system suitable for teaching? For that it is necessary:

- to evaluate the nature of the problems to be solved;

- to evaluate the available hardware level;

- to evaluate the user's qualification,

- because a limited period of time is allocated for practical teaching of mathematics, CMS have to be quickly internalised;

- the user of the system (a student) does not have special skills, that is why CMS

have to provide detailed information about the diagnostics of mistakes and to have a comfortable help system.

Some CMS have demonstration versions, that is why they are suitable for selfteaching.

\section{The opportunities of introducing CMS in secondary schools}

We shall try to explore and analyse teachers' and student's prejudices and opinions towards the introduction of CMS in the process of teaching. For that purpose the following topics have been analysed:

- what determines the application of CMS in teaching process;

- what obstacles interfere with the introduction of CMS in teaching;

- what students know about CMS, what systems they would like to work with and where they would use them;

- what teachers think about the possibilities to use CMS in teaching process;

- what experience teachers have.

The use of CMS in a secondary school is determined by a number of faciors:

- the change in the syllabus on Mathematics - instead of being oriented towards fragmented knowledge of different subjects, students are presented with the problem to be solved;

- increased opportunities to acquire PCs (a decrease in prices, user-friendly software, some CMS versions can be found free on the Internet);

- IT topics at school and university are affected by ECDL standard;

- the development of information skills started to be integrated in the overall process of education;

- the results of the survey conducted among the students of Vilnius Pedagogical University (Valavičius, 2001) show that a subject called "Computer in the Subject Class" should be taught at universities in Lithuinia;
- some topics are difficult to teach without a computer, e.g., graphs, polyhedrons, surfaces, etc.

CMS can be introduced to students in a variety of ways:

1. During classes on informatics - through work with CMS.

2. During other subject classes (e.g., mathematics, physics, etc.) the CMS opportunities can be demonstrated while explaining new concepts, memorizing, establishing links among the objects, etc.

3. In clubs and elective classes - through further analysis of CMS possibilities, e.g. graphics, animation, etc. Of course, only those students who have chosen the class are going to work here.

The second way is difficult to realize so far because not every Physics or Maths class has computers. However, even if there is no computer class in which maths classes could take place, one good computer would allow the teacher to prepare a lot of drawings, illustrations, tests, and various problems. Besides, not all the teachers of other subjects are computer literate and know how to use CMS. That is why we were more interested in the first way.

The sample: 74 students of Grades $9-12$. They have been introduced with MAPLE, MATHCAD, MATHEMATICA and MATLAB systems. That is why it was interesting to find out which system they would like to work with and why. It follows from the pupils' responses (see Fig. 1), that they liked MAPLE system most (simple communication, easier to interface with special packages, a simple input command), followed by MATHCAD (they didn't have to write many commands, instead one can use a symbol palette). Only $1.5 \%$ didn't like any system. In general the choice of CMS was motivated by the following aspects: the comfort of the user's graphical interface, possibilities of drawing graphic objects, drawing colours, the comfort of the input line, however, they didn't stress problem solving possibilities of the CMS.

Another question allowed the students to evaluate their understanding of where they would use CMS. The main answers to this question are in diagram form in Fig. 2.

It has been noticed that most of the students' will used the CMS to check the result of the solutions and to make the drawings of the problem. There is a wish to try the novelty.

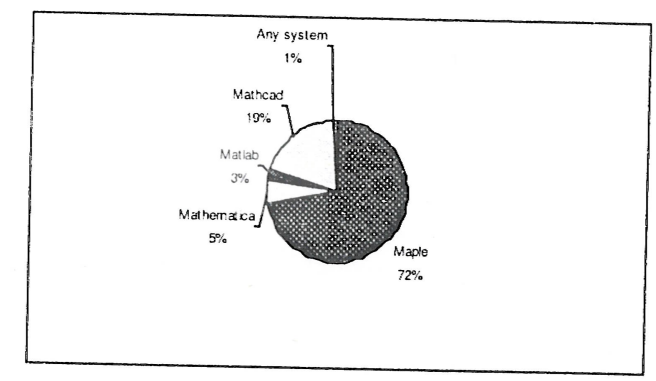

Fig. 1. The choise of CMC. 


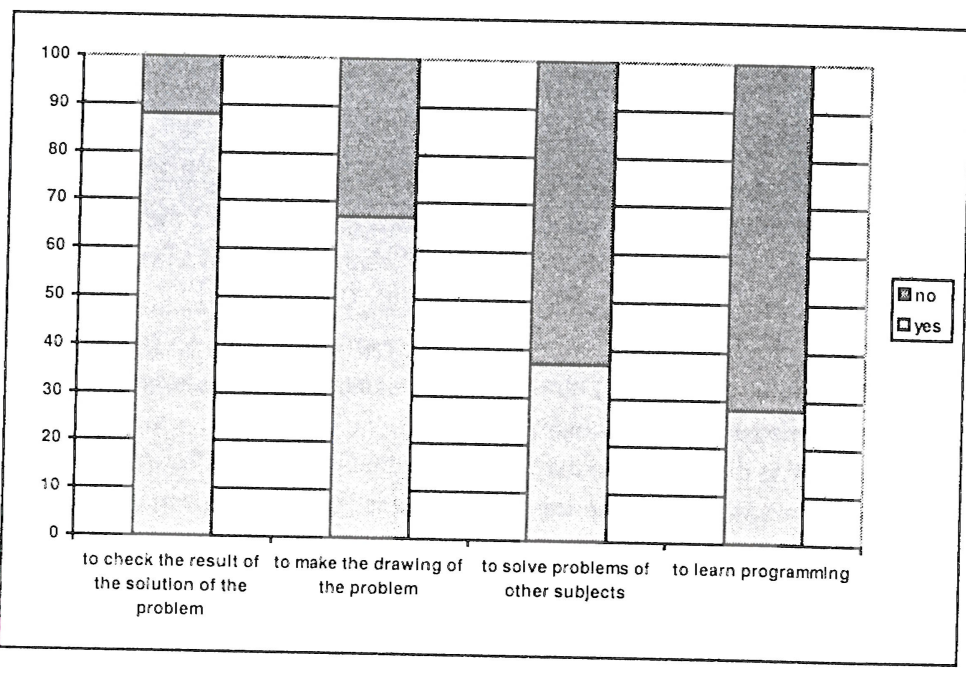

Fig. 2. The answers of the students' about the applicability of CMS.

CMS usefulness for teachers:

- to generate teaching tasks;

- to solve the problems; - to prepare visual materials for the class to explain new concepts, help memorizing
things, etc.;

- in Physics classes to model phenomena, to use spreadsheets to process the results of lab experiments, as a tool for drawing diagrams, etc.;

- for testing.

Thus the use of computer technologies in the process of teaching can be of different forms: in theory classes - as a means of material presentation and demonstration, in laboratory experiments - as a virtual test bench which does not require actual materials, in practice classes - as a calculator, at home - as a means of independent work and testing.

We could not see a purposeful employment of the systems from the answers maybe because the respondents have not experienced concrete results of using CMS. This shows that most respondents (teachers and students) do not realize exactly what the process offers. That is why special reseilrch is needed to evaluate how computer technology affects separate areas of mathematics.

What are the obstacles preventing the introduction of computer technologies in teaching mathematics? The main are as follows: the lack of computers, the lack of knowledge and skills on the part of the subject teachers, the lack of special software for teaching, difficulties in integrating computers into the teaching activities in the ciassroom, etc. On the basis of these answers one can arrive at a conclusion that computer integration in teaching mathematics has to do not only with social but aiso with pedagogical aspects.
The use of computer technologies in teaching mathematics is determined not only by the quality of preparatory and teacher's work, but also students' prejudices towards the use of the computer, their computer literacy and skills, learning styles, etc. Neither teachers nor students are against the changes in the usual way of teaching and tend to believe in success while applying the new things. The results of the initial survey suggest hat students are interested in CMS and that CMS are necessary in the teaching process.

Both reviewed and original research shows how important is the use of computer technologies for solving mathematical problems: it changes the environment of the class, the teacher's role, the teacher-pupils' relations, the teaching process becomes more varied, more intensive and dynamic, not a constant repetition of standard problems.

\section{Conclusions}

1. The results of the survey show that now is the best time to integrate various computer technologies into the teaching of mathematics. It is only the lack of computers and teaching methodologies that limits their application on all the levels of the study of mathematics. There is a wish to introduce CMS in the process of teaching.

2. Not many schools in Lithuania can legally use a CMS (or a few CMS). It is enough to choose one because their general-purpose possibilities are similar. Among the systems popular in Lithuania, students' needs should be satisfied by either MAPLE or MATHCAD systems.

3. Teaching by the use of the computer should gradually change the ratio between "the classes with a computer" and "classes without a computer".

4. This survey must be regarded as a pilot one, that is why its results cannot be applied to the whole teacher-student population. In the future a greater quantity of students are going to be surveyed.

\section{References}

Adomavičius, J., E. Bareiša, V. Keršienẻ and M. Pečílikovienè (1999). Informatika 2, Kaunas, Technologija (in Lithunian).

Barila, A., L. Bariliené, A. Jakutavičius and R. Palevičius (2001). Informatika 2, Kaunas, Technologija (in Lithunian).

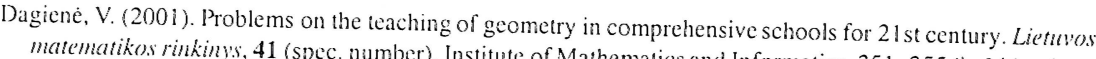

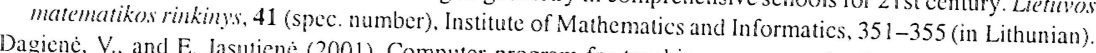
Dagiené, V.. and E. Jasutiene (2001). Computer program for teaching geometry. In Kompiuterininkly dienoss
2001, pp. 100-103(in Lithunian).

Denisovas, V. (2000). Modelling across the curriculum. Informatika, 36, 5-35 (in Lithunian).

Domarkas A., R. Rakauskas and $S$. Cicénas (2001). The conjunction between computer algebra and numerical methods. Lietwoss matematikes rinkinys, 41 (spec. number). Institute of Mathematics and Informatics, 184-
190 (in Lithunian).

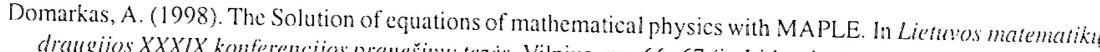
draugijos XXXIX konferencijos pranešimultezés, Vilnius, pp. 60-67 (in Lithunian). Judickaitc, V., R. Kulvietienè and G. Kulvietis (2001). Parallel computer algebra system. Lietuvos matematikos
rinkinys, $\mathbf{4 1}$ (spec. number). Institute of Mathematics and Informing 
The Lithuanian school syllabus for Mathematics (1997). Vilnius, pp. 206-280 (in Lithuanian).

Lipeikienè, J. (2000). Teaching geometry with computer. Lietuvos matematikos rinkinys, 40 (spec. number), Institute of Mathematics and Informatics, 232-239 (in Lithunian).

Serrikovienè, S. (2001). On the links between mathematical software package Mathcad and Excel. Lietuvos matematikos rinkiny", 41 (spec. number). Institute of Mathematics and Informatics, 330-334 (in Lithunian). Rudzkiené, V. (2000). Quasi - random numbers in some statistical systems. Lietuvos matematikos rinkinys, 40 (spec. number), Institute of Mathematics and Informatics, 111-116 (in Lithunian).

Rudzkiené, V. (2001). Statistical packages in teaching process. Informacijos mokslai, 18, 49-52 (in Lithunian) Turskiené, S. (2001). Findamentals of working with the MAPLE, Šiauliai (in Lithunian).

Turskienè, S. (1997). The work with MATHEMATICA, Šiauliai (in Lithunian).

Turskiené, S. (2002). Computer mathematics systems in teaching process. Lietuvos matematiku draugijos XIII konferencilija, Vilnius (in Lithunian)

Using Computer Algebra systems in Educational Process (2002).

http://www.geocities.com/psigita(in Lithuanian).

Valavičius. E. (2001). Alterations in teaching of information and communication technology at Vilnius pedagogical University. Informarijos mokslai, 18, 53-58 (in Lithunian)

S.Turskienè is an associate professor at the Department of Computer Science of Šiauliai University. Her major research interests are computational mechanics, implementation of information technology in education.

\section{Kompiuterinè technologija ir matematikos mokymas vidurinèse \\ mokyklose}

\section{Sigita TURSKIENE}

Straipsnyje ivairiais aspektais analizuojamos labiausiai Lietuvoje paplitusios kompiuteriné teclnologijos, kurios tiesiogiai skirtos arba gali būti nesunkiai pritaikytos matematikos uždaviniams spręsti. Aptariamos svarbiausios kompiuterinių technologiju diegimo mokymo procese galimybès ir probiemos.

Straipsnyje nagrinéjamos mokytoju ir moksleiviu išankstinès nuostatos kompiuteriniu technologijụ diegimo matematikos mokyme atžvilgiu. Iš gautų rezultatų matyti, kad dabar pats tinkamiausias metas Lietuvoje kuo plačiau integruoti ivairias kompiuterines technologijas ị matematikos mokyma. 